\title{
Cidadania terrena e Cidadania divina: um estudo de caso de uma campanha eleitoral evangélica pentecostal
}

\section{Adriel Torres de Q. Ferreira*, Prof. Dr. Ronaldo Rômulo Machado de Almeida.}

\section{Resumo}

Esta pesquisa consiste num estudo de caso realizado nas eleições de 2018, na qual observei a campanha eleitoral de uma candidato oficial da igreja evangélica pentecostal Assembléia de Deus (AD) ministério Belém em Campinas. Esta estratégia eleitoral da candidatura oficial não se restringe a declaração de apoio a determinado candidato pela igreja, pois a instituição religiosa assume um papel centralizador, selecionando o candidato, coordenando a campanha, recrutando e formando uma militância, além de ceder os espaços das reuniões religiosas para divulgação da candidatura. Observei, então, a campanha a reeleição do Pastor presidente da AD Belém em Campinas, Paulo Roberto Freire da Costa (PR), afim de reconhecer qualitativamente a suposta profissionalização das campanhas eleitorais evangélicas e a a importância da atuação da igreja para o sucesso eleitoral da candidatura oficial.

\section{Palavras-chave:}

Religião, eleição, evangélicos.

\section{Introdução}

A literatura sobre está temática tem investigado a crescente participação evangélica na política institucional e afirmado um sucesso eleitoral dos evangélicos pentecostais decorrente das singularidades de suas campanhas eleitorais. Segundo Netto (2016) as candidaturas evangélicas tendem a ter um sucesso eleitoral de forma mais barata. Isso ocorre por contarem com o apoio das lideranças religiosas, que podem se tornar mobilizadores de voto (Nascimento, 2017) e, um eleitorado cativo, que podem se tornar uma militância voluntária (Almeida e Peixoto, 2017) além de utilizarem os templos como local de divulgação das candidaturas (Valle, 2013). Essas singularidades são apreendidas pela estratégia eleitoral das Igrejas pentecostais de lançar as candidatos oficiais. Esse fenômeno de profissionalização das candidaturas evangélicas foi, na maioria dos estudos da literatura, avaliados a partir das campanhas eleitorais da Igreja Universal do Reino de Deus (IURD), porém, esta mesma literatura afirma que o sucesso político da IURD tem produzido um efeito mimético em outras igrejas pentecostais (Oro, 2003; Almeida, 2004). Portanto esta pesquisa busca colaborar realizando um esforço qualitativo neste estudo de caso da $A D$ Belém procurando as características de sua profissionalização da campanha e a atuação central, determinante para o sucesso eleitoral, da instituição religiosa.

\section{Resultados e Discussão}

A observação foi realizada com a metodologia da etnografia política do Valle (2013). Utilizei, também, estatística descritiva para os dados referentes ao financiamento de campanha do candidato analisado em diálogo com a tese da Netto (2016). A observação de campo confirmou a profissionalização seguindo este modelo de representação corporativa, as candidaturas oficiais. A centralidade da instituição religiosa na campanha do Paulo (PR) foi observada na existência e atuação de um projeto criado pela da $A D$ Belém para coordenar sua participação política. O Projeto Cidadania $A D$ formou um conselho político que seleciona os candidatos, coordena a campanha, recruta os cabos eleitorais, além de realizar reuniões de formação política fechadas com os pastores, afim de formá-los como mobilizadores de voto. Sobre o financiamento o deputado teve o custo do voto mais caro em comparação aos demais candidatos evangélicos oficiais. Os atores da campanha justificam esse alto custo do voto pela dificuldade de transportar material para todos os templos da AD Belém de SP. Obtivemos o resultado, então, que o valor adicional despendido para assegurar o sucesso eleitoral do candidato Paulo (PR) foi empregado numa maior divulgação da candidatura oficial para a base social da AD ministério Belém.

\section{Conclusões}

Concluímos que o fenômeno de profissionalização das campanhas, aqui observado, acontece e, sob a estratégia eleitoral da candidatura oficial. Esta estratégia eleitoral na qual a igreja concede espaço, pessoas e serviços, cria uma campanha eleitoral dependente do apoio e atuação da igreja, ao mesmo tempo em que a campanha não depende significativamente da rede de relações e carisma do candidato. O sucesso eleitoral se dá sobre a rede de relações, a conversão de base eclesiástica em eleitorado e carisma, não do candidato mas da Instituição religiosa.

\section{Agradecimentos}

Agradeço ao CNPQ pela bolsa de pesquisa. Também agradeço a orientação do Prof. Dr. Ronaldo Rômulo Machado de Almeida e aos orientandos Gabriel Kikumoto e Gabriella Gontijo pela elaboração dos dados quantitativos.

ALMEIDA, Jheniffer Vieira De e PEIXOTO, Vitor. Servir e Obedecer: uma análise de cabos eleitorais neopentecostais. In: 41 ENCONTRO ANUAL DA ANPOCS, 2017, Caxambu, MG. Anais... Caxambu, MG.: [s.n.], 2017.

LACERDA, Fábio. Pentecostalismo, Eleições e Representação política no Brasil Contemporâneo. Tese de Doutorado (Ciência Política). Universidade de São Paulo, São Paulo. 2017.

NASCIMENTO, Claudia Cerqueira. Igreja como partido: capacidade de coordenação eleitoral da Igreja Universal do Reino de Deus. Tese (Doutorado em Ciência Política). - Fundação Getúlio Vargas, São Paulo, 2017. NETTO, Gabriela Figueiredo. Quando o dinheiro importa menos: uma análise do financiamento de campanhas eleitorais dos candidatos evangélicos. Dissertação de Mestrado (Ciência Política). Universidade de São Paulo, São Paulo, 2016.

VALLE, Vinicius Saragiotto Magalhães do (2013). Pentecostalismo e lulismo na periferia de São Paulo: estudo de caso sobre uma Assembleia de Deus na eleição municipal de 2012. Dissertação (Mestrado em Ciência Política) Faculdade de Filosofia, Letras e Ciências Humanas, Universidade de São Paulo, São Paulo, 2013. 